\title{
Learning for the Knowledge Society
}

\author{
Ivana Tichá \\ Czech University of Agriculture, Prague
}

\begin{abstract}
Summary: With sustained use and creation of knowledge in the centre of the economic development process, an economy essentially becomes a Knowledge Economy. A Knowledge Economy (KE) is one that utilizes knowledge as the key engine of economic growth. It is an economy where knowledge is acquired, created, disseminated and used effectively to enhance economic development.
\end{abstract}

Keywords: knowledge society, knowledge economy index, innovation systems, education

It can be argued that the knowledge economy differs from the traditional economy in several key respects:

- Economics is not of scarcity, but rather of abundance. Unlike most resources that are depleted when used, information and knowledge can be shared, and actually grown through application.

- The effect of location is either

1. diminished, in some economic activities: using appropriate technology and methods, virtual marketplaces and virtual organizations that offer benefits of speed, agility, round the clock operation and global access can be created.

2. or, on the contrary, reinforced in some other economic fields, by the creation of Porter's clusters around centres of knowledge, such as universities and research centres having reached world-wide excellence.

- Laws, barriers and taxes are difficult to apply on solely a national basis. Knowledge and information "leak" to where demand is the highest and barriers are the lowest.

- Knowledge enhanced products or services can command price premiums over comparable products with low embedded knowledge or knowledge intensity.

- Pricing and value depend heavily on context. Thus the same information or knowledge can have vastly different values to different people or even to the same person at different times.

- Knowledge when locked into systems or processes has higher inherent value than when it can "walk out of the door" in people's heads.

- Human capital - competencies - are key components of value in a knowledge-based company, yet few companies report competency levels in annual reports. In contrast, downsizing is often seen as a positive "cost cutting" measure.

These characteristics require new ideas and approaches from policy makers, managers and knowledge workers (Wikipedia).
It has been found that successful transition to the Knowledge Economy typically involves elements such as long-term investments in education, developing innovation capability, modernizing the information infrastructure, and having an economic environment that is conducive to market transactions. These elements have been termed by the World Bank (Chen and Dahlman, 2005) as the pillars of the Knowledge Economy and together they constitute the Knowledge Economy framework.

More specifically, the four pillars of the Knowledge Economy (KE) framework are as follows:

- An economic incentive and institutional regime that provides good economic policies and institutions that permit efficient mobilization and allocation of resources and stimulate creativity and incentives for the efficient creation, dissemination, and use of existing knowledge.

- Educated and skilled workers who can continuously upgrade and adapt their skills to efficiently create and use knowledge.

- An effective innovation system of firms, research centres, universities, consultants, and other organizations that can keep up with the knowledge revolution and tap into the growing stock of global knowledge, assimilate and adapt it to local needs.

- A modern and adequate information infrastructure that can facilitate the effective communication, dissemination, and processing of information and knowledge. The Knowledge Economy framework thus asserts that investments in the four knowledge economy pillars are necessary for sustained creation, adoption, adaptation and use of knowledge in domestic economic production, which will consequently result in higher value added goods and services. This would tend to increase the probability of economic success, and hence economic development, in the current highly competitive and globalized world economy. 


\section{Comparison of V4 Countries with the use of Knowledge Assessment Methodology}

The Knowledge Assessment Methodology (KAM) was designed by the World Bank Institute to proxy a country's preparedness to compete in the knowledge economy using more then 80 structural and qualitative variables. The comparison is undertaken for a group of 128 countries, which includes most of the OECD economies and more than 90 developing countries. To allow for a flexible crosscountry comparison, each variable is available in both actual and relative value (normalized on a scale from zero to ten relative to other countries in the comparison group.)

The unique strength of the KAM methodology is its cross-sectoral approach, allowing the user to take a holistic view of a wide range of relevant factors rather than just focusing on one area. The variables serve as proxies for the four pillars of the Knowledge Economy framework:

- An economic and institutional regime to provide incentives for the efficient use of existing and new knowledge and the flourishing of entrepreneurship;

- An educated and skilled population to create, share, and use knowledge well;

- An efficient innovation system of firms, research centres, universities, consultants and other organizations to tap into the growing stock of global knowledge, assimilate and adapt it to local needs and create new technology;

- Information and communication technology to facilitate the effective creation, dissemination, and processing of information.

Several variables are included in the KAM that track the overall performance of an economy. These variables help to illustrate how well an economy is actually using knowledge for its overall economic and social development.

The KAM offers several pre-set display modes for the simple visual representations of a country's readiness for the Knowledge Economy. A country can be assessed and compared with others on the aggregate performance of each KE pillar or the overall Knowledge Economy and Knowledge indexes for 1995, together with the most recent available year. The KAM also makes possible customized country analysis and cross-country comparison on the indicators hand-picked by the user. This allows for capturing various aspects of a country's ability to generate, diffuse and apply knowledge for economic development.

The KAM Knowledge Index (KI) measures a country's ability to generate, adopt and diffuse knowledge. This is an indication of overall potential of knowledge development in a given country. Methodologically, the $\mathrm{KI}$ is the simple average of the normalized performance scores of a country or region on the key variables in three Knowledge Economy pillars education and human resources, the innovation system and information and communication technology (ICT).

The Knowledge Economy Index (KEI) takes into account whether the environment is conducive for knowledge to be used effectively for economic development. It is an aggregate index that represents the overall level of development of a country or region towards the Knowledge Economy. The KEI is calculated based on the average of the normalized performance scores of a country or region on all four pillars related to the knowledge economy - economic incentive and institutional regime, education and human resources, the innovation system and ICT.

For the purposes of calculating KI and KEI, each pillar is represented by three key variables:

\section{The Economic Incentive and Institutional Regime}

- Tariff \& Non-tariff Barriers

- Regulatory Quality

- Rule of Law

\section{Education and Human Resources}

- Adult Literacy Rate

- Secondary Enrolment

- Tertiary Enrolment

\section{The Innovation System}

- Researchers in R\&D

- Patent Applications Granted by the US Patent and Trademark Office

- Scientific and Technical Journal Articles

These three variables are available in two forms: scaled by population and in absolute values. Thus, both KI and KEI are also available in "weighted" and "unweighted" forms. In innovation, absolute size of resources matters, as there are strong economies of scale in the production of knowledge and because knowledge is not consumed in its use.

Table 1: Comparison of V4 Countries - Knowledge Economy Index

\begin{tabular}{|c|c|c|c|c|c|c|c|c|}
\hline \multirow[t]{2}{*}{ VARABLE } & \multicolumn{2}{|c|}{ POLAND } & \multicolumn{2}{|c|}{ SLOVAKIA } & \multicolumn{2}{|c|}{ HUNGARY } & \multicolumn{2}{|c|}{ CZECH REPUBLIC } \\
\hline & actual & nomalized & actual & normalized & actual & normalized & actual & normalized \\
\hline GDP growth(\%) & 3,08 & 3,07 & 4,08 & 5,04 & 3,9 & 4,96 & 3,14 & 3,39 \\
\hline Huthan Developtnent Index & 0,858 & 7,3 & 0,849 & 6,83 & 0,862 & 7,38 & 0,874 & 7,54 \\
\hline Tariff \& nontariff barriers & 2 & 7,04 & 2 & 7,04 & 2 & 7,04 & 2 & 7,04 \\
\hline Regulatoxy Quality & 0,64 & 6,64 & 1,15 & 7,97 & 1,22 & 8,12 & 0,97 & 7,5 \\
\hline Rule of Law & 0,51 & 6,41 & 0,49 & 6,33 & 0,85 & 7,58 & 0,69 & 6,95 \\
\hline Researchers in R\&D / million & 1468,57 & 5,35 & 1706,82 & 6,05 & 1473,07 & 5,47 & 1466,6 & 5,23 \\
\hline $\begin{array}{l}\text { Scientific and technical journal } \\
\text { articles / mil. pop. }\end{array}$ & 148,65 & 7,32 & 177,54 & 7,48 & 243,35 & 7,72 & 256,46 & 7,87 \\
\hline $\begin{array}{l}\text { Patent applications granted by } \\
\text { the USPTO/mil. pop. }\end{array}$ & 0,5 & 5,78 & 0,93 & 6,56 & 5,16 & 7,81 & 3,14 & 7,66 \\
\hline $\begin{array}{l}\text { Adult literacy rate (\% age } 15 \\
\text { and above) }\end{array}$ & 100 & 8,19 & 100 & 8,19 & 99,36 & 7,32 & 100 & 8,19 \\
\hline Secondary Enrolment & 101,27 & 8,28 & 89,46 & 6,17 & 103,6 & 8,52 & 95,81 & 7,34 \\
\hline Tertiary Entrolthent & 59,51 & 8,48 & 32,11 & 5,6 & 44,09 & 7,12 & 33,66 & 5,76 \\
\hline Telephones per 1,000 people & 917,6 & 6,48 & 1022 & 6,95 & 1251,6 & 7,73 & 1390,7 & 8,52 \\
\hline Computers per 1,000 people & 191 & 6,83 & 294,6 & 7,5 & 150,1 & 6,42 & 239,6 & 7,25 \\
\hline $\begin{array}{l}\text { Internet users per 10,000 } \\
\text { people }\end{array}$ & 2334,57 & 6,48 & 4209,36 & 7,97 & 2746,4 & 6,8 & 4693,92 & 8,12 \\
\hline
\end{tabular}




\section{Information and Communication Technology \\ (ICT)}

- Telephones per 1,000 people

- Computers per 1,000 people

- Internet Users per 10,000 people

The scorecard also presents two variables related to the overall economic and social performance.

\section{Overall Performance of Economy}

- Average Annual Gross Domestic Product (GDP) Growth, 1994-98 and 2000-2004 (\%) (DDP). Annual GDP growth is a good indicator of a country's overall economic development.

- Human Development Index (HDI), 2003 (UNDP Human Development Report 2005). HDI is a composite measure of three components: longevity (measured by life expectancy); knowledge (adult literacy rate and mean years of schooling); and standard of living (real GDP per capita in purchasing power parity). The HDI provides information on the human development aspect of economic growth.

The above comparison shows very much similar patterns for all countries in comparison. This can be most likely accounted to similar historical development of all four countries. Following comparisons focus in more details onto selected pillars of knowledge economy: innovation systems, education and ICT.

\section{European Initiatives to Enhance Knowledge Economy}

The creation of a Europe of knowledge has been a prime objective for the European Union since the Lisbon European Council of March 2000. Subsequent European Councils, particularly Stockholm in March 2001 and Barcelona in March 2002, have taken the Lisbon objective further forward. To implement the Lisbon agenda, the European Union has embarked upon a series of actions and initiatives in the areas of research and education. One example is the European area of research and innovation, to achieve which fresh perspectives have been already opened up and, in this context, the objective to increase the European research and

\section{Knowledge Economy Index}

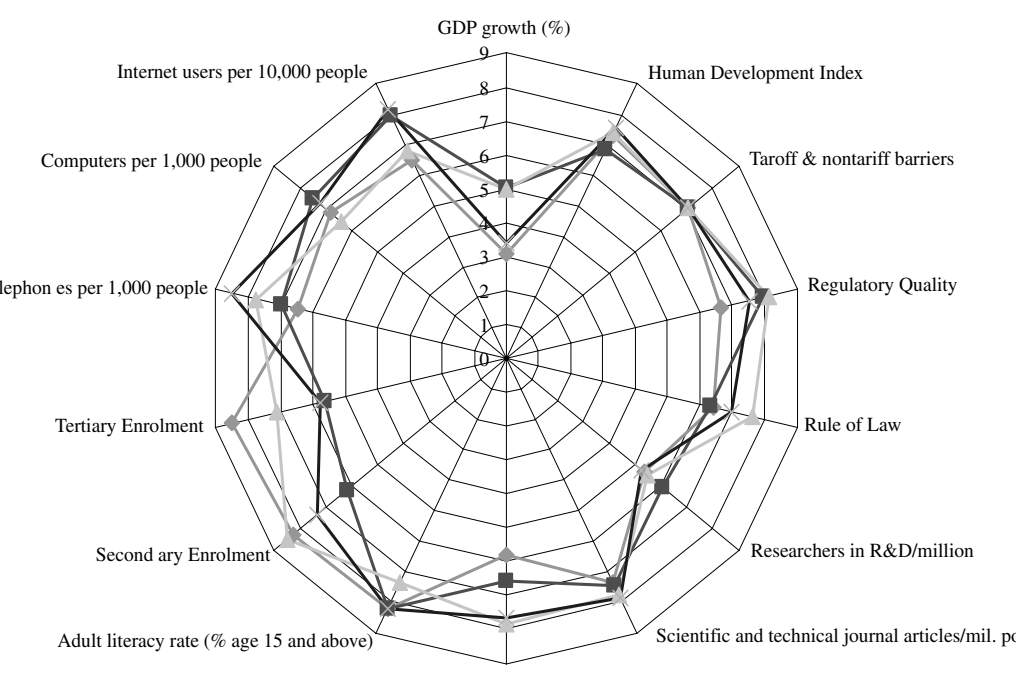

Patent applications granted by the USPTO/mil. pop

$\leadsto$ POLAND $\because$-SLOVAKIA $\leadsto$ HUNGARY $\rightarrow$ CZECHREPUBUC

Graph 1: Comparison of V4 Countries - Knowledge Economy Index

development drive to $3 \%$ of the Union's GDP by 2010. (EC, 2003)

In the area of education and training, the following achievements are worth mentioning:

- European area of lifelong learning,

- the implementation of the detailed work programme on the objectives of education and training systems,

- work to strengthen the convergence of higher education systems, in line with the Bologna process,

- and vocational training systems, in line with the Copenhagen declaration.

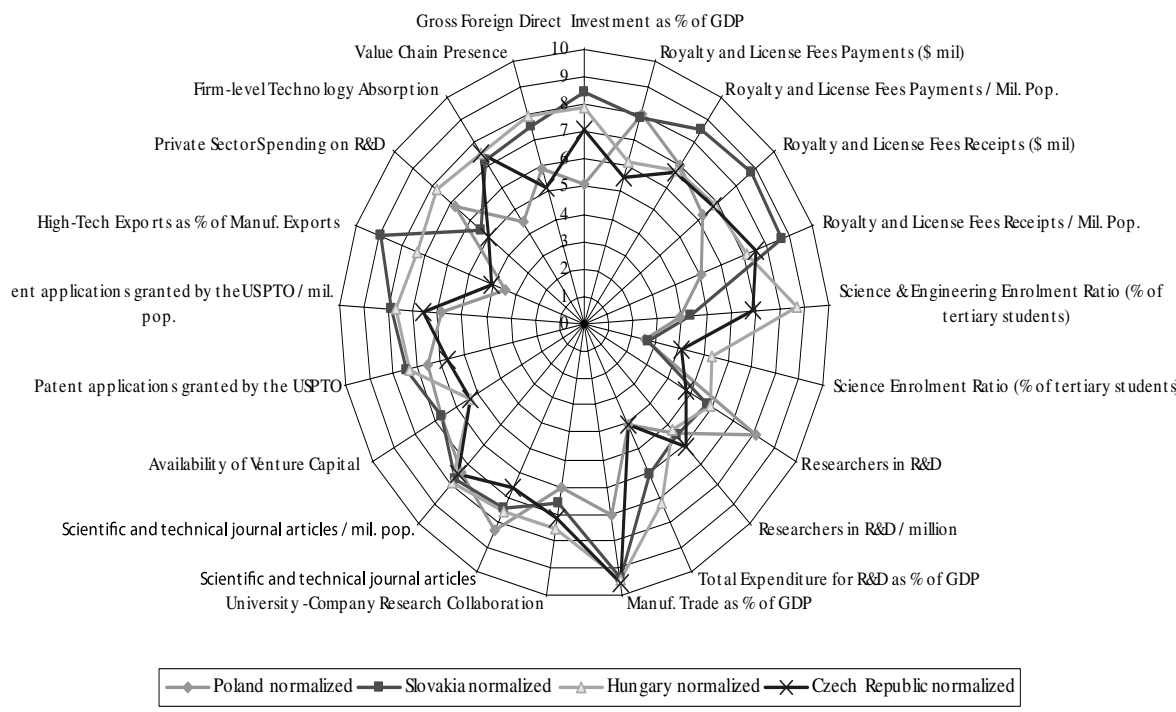

Graph 2: Comparison of V4 Countries - Innovation systems 
Table 2: Comparison of V4 Countries - Selected pillars

\begin{tabular}{|c|c|c|c|c|c|c|c|c|}
\hline \multirow[t]{2}{*}{ VARIABLE } & \multicolumn{2}{|c|}{ Poland } & \multicolumn{2}{|c|}{ Slovakia } & \multicolumn{2}{|c|}{ Hungary } & \multicolumn{2}{|c|}{ Czech Republic } \\
\hline & actual & normalized & actual & normalized & actual & normalized & actual & normalized \\
\hline \multicolumn{9}{|c|}{ INNOVATIO N SYSTEM S } \\
\hline $\begin{array}{l}\text { Gross Foreign Direct Investment } \\
\text { as \% of GDP }\end{array}$ & 3,69 & 5,04 & 8,1 & 8,38 & 6,33 & 7,86 & 5,32 & 7,01 \\
\hline $\begin{array}{l}\text { Royalty and License Fees } \\
\text { Payments (\$ mil) }\end{array}$ & 875 & 7,96 & 857,9 & 7,86 & 175,9 & 6,12 & 91,2 & 5,53 \\
\hline $\begin{array}{l}\text { Royalty and License Fees } \\
\text { Payments / Mil. Pop. }\end{array}$ & 22,91 & 6,89 & 84,94 & 8,54 & 17,24 & 6,7 & 16,92 & 6,6 \\
\hline $\begin{array}{l}\text { Royalty and License Fees } \\
\text { Receipts (\$ mil) }\end{array}$ & 27 & 6,26 & 508,5 & 8,69 & 50,3 & 6,87 & 49,7 & 6,77 \\
\hline $\begin{array}{l}\text { Royalty and License Fees } \\
\text { Receipts / Mil. Pop. }\end{array}$ & 0,71 & 5,05 & 50,35 & 8,59 & 4,93 & 7,07 & 9,2 & 7,47 \\
\hline $\begin{array}{l}\text { Science \& Engineering } \\
\text { Enrolment Ratio ( } \% \text { of tertiary } \\
\text { students) }\end{array}$ & 20,06 & 3,86 & 20,97 & 4,34 & 30,71 & 8,67 & 26,56 & 6,87 \\
\hline $\begin{array}{l}\text { Science Enrolment Ratio (\% of } \\
\text { tertiary students) }\end{array}$ & 6,46 & 2,53 & 6,76 & 2,65 & 10,27 & 5,3 & 8,67 & 4,1 \\
\hline Researchers in $\mathrm{R} \& \mathrm{D}$ & 58595 & 8,02 & 15180 & 5,81 & 15809 & 5,93 & 9626 & 4,77 \\
\hline Researchers in R\&D / million & 1468,57 & 5,35 & 1473,07 & 5,47 & 1466,6 & 5,23 & 1706,82 & 6,05 \\
\hline $\begin{array}{l}\text { Total Expenditure for R\&D as \% } \\
\text { of GDP }\end{array}$ & 0,59 & 4,1 & 1,01 & 6,02 & 1,3 & 7,23 & 0,59 & 4,1 \\
\hline \begin{tabular}{|l|} 
Manuf. Trade as \% of GDP \\
\end{tabular} & 46,57 & 6,95 & 94,59 & 9,32 & 95,99 & 9,41 & 113,84 & 9,49 \\
\hline $\begin{array}{l}\text { University-Company Research } \\
\text { Collaboration }\end{array}$ & 3,2 & 6 & 3,3 & 6,55 & 3,9 & 7,55 & 3,5 & 7,09 \\
\hline $\begin{array}{l}\text { Scientific and technical journal } \\
\text { articles }\end{array}$ & 5686 & 8,35 & 2479 & 7,4 & 2622 & 7,56 & 955 & 6,61 \\
\hline $\begin{array}{l}\text { Scientific and technical journal } \\
\text { articles / mil. pop. }\end{array}$ & 148,65 & 7,32 & 243,35 & 7,72 & 256,46 & 7,87 & 177,54 & 7,48 \\
\hline Availability of Venture Capital & 3,6 & 6,64 & 3,6 & 6,64 & 3,3 & 5,36 & 3,3 & 5,36 \\
\hline $\begin{array}{l}\text { Patent applications granted by } \\
\text { the USPTO }\end{array}$ & 19 & 6,56 & 52 & 7,42 & 32 & 7,27 & 5 & 5,7 \\
\hline $\begin{array}{l}\text { Patent applications granted by } \\
\text { the USPTO / mil. pop. }\end{array}$ & 0,5 & 5,78 & 5,16 & 7,81 & 3,14 & 7,66 & 0,93 & 6,56 \\
\hline $\begin{array}{l}\text { High-Tech Exports as \% of } \\
\text { Manuf. Exports }\end{array}$ & 3,07 & 3,48 & 25,63 & 8,87 & 13,23 & 7,3 & 3,72 & 4 \\
\hline $\begin{array}{l}\text { Private Sector Spending on } \\
\text { R\&D }\end{array}$ & 3,5 & 6,82 & 3,2 & 5,45 & 3,9 & 7,73 & 3,1 & 5 \\
\hline $\begin{array}{l}\text { Firm-level Technology } \\
\text { Absorption }\end{array}$ & 4,5 & 4,43 & 5,2 & 7,17 & 5,3 & 7,45 & 5,3 & 7,45 \\
\hline Value Chain Presence & 3,9 & 5,85 & 4,7 & 7,45 & 5 & 7,92 & 3,8 & 5,19 \\
\hline \multicolumn{9}{|c|}{ EDUCATION } \\
\hline $\begin{array}{l}\text { Adult literacy rate (\% age } 15 \text { and } \\
\text { above) }\end{array}$ & 100 & 8,19 & 99,36 & 7,32 & 100 & 8,19 & 100 & 8,19 \\
\hline \begin{tabular}{|l|} 
Average Years of Schooling \\
\end{tabular} & 9,84 & 8,7 & 9,1 & 7,17 & 9,48 & 8,26 & 9,27 & 7,39 \\
\hline Secondary Enrollment & 101,27 & 8,28 & 103,6 & 8,52 & 95,81 & 7,34 & 89,46 & 6,17 \\
\hline Tertiary Enrollment & 59,51 & 8,48 & 44,09 & 7,12 & 33,66 & 5,76 & 32,11 & 5,6 \\
\hline Life Expectancy at Birth (years) & 74,6 & 6,88 & 72,6 & 5,55 & 75,2 & 7,19 & 73,4 & 5,94 \\
\hline Internet Access in Schools & 4,1 & 5,82 & 5,1 & 7,36 & 5,2 & 7,55 & 4,9 & 7,18 \\
\hline $\begin{array}{l}\text { Public Spending on Education as } \\
\% \text { of GDP }\end{array}$ & 5,6 & 7,48 & 5,1 & 6,52 & 4,2 & 4,52 & 4 & 3,91 \\
\hline $\begin{array}{l}\text { Prof. and Tech. Workers as \% of } \\
\text { the Labor Force }\end{array}$ & 25 & 6,67 & 27,08 & 7,44 & 29,4 & 8,46 & 28,68 & 7,82 \\
\hline $\begin{array}{l}\text { 8th Grade Achievement in } \\
\text { Mathematics }\end{array}$ & $\mathrm{n} / \mathrm{a}$ & $\mathrm{n} / \mathrm{a}$ & 529 & 7,71 & 520 & 7,29 & 508 & 6,46 \\
\hline $\begin{array}{l}\text { 8th Grade Achievement in } \\
\text { Science }\end{array}$ & $\mathrm{n} / \mathrm{a}$ & $\mathrm{n} / \mathrm{a}$ & 543 & 8,54 & 539 & 8,33 & 517 & 6,04 \\
\hline $\begin{array}{l}\text { Quality of Science and Math } \\
\text { Education }\end{array}$ & 5,1 & 7,73 & 5,3 & 8,73 & 5,7 & 9,45 & 5,2 & 8,18 \\
\hline Extent of Staff Training & 3,8 & 5,45 & 3,8 & 5,45 & 4,5 & 7,45 & 4,1 & 6,36 \\
\hline $\begin{array}{l}\text { Availability of Management } \\
\text { Education }\end{array}$ & 4,4 & 5,45 & 4,7 & 6,64 & 4,9 & 7,09 & 4,2 & 5,18 \\
\hline Brain Drain & 3,4 & 5,55 & 3,6 & 5,82 & 4,1 & 6,73 & 3,2 & 4,73 \\
\hline \multicolumn{9}{|c|}{ INFORM ATIO N AND COMMUNIACT ION TECH NOLOGY } \\
\hline Telephones per 1,000 people & 917,6 & 6,48 & 1251,6 & 7,73 & 1390,7 & 8,52 & 1022 & 6,95 \\
\hline $\begin{array}{l}\text { Main Telephone Lines per } 1000 \\
\text { People }\end{array}$ & 318,5 & 7,11 & 363,9 & 7,42 & 337,4 & 7,19 & 231,3 & 5,78 \\
\hline Mobile Phone per 1,000 People & 599,1 & 6,56 & 887,7 & 8,28 & 1053,3 & 9,69 & $\begin{array}{ll}790,7 \\
\end{array}$ & 7,42 \\
\hline Computers per 1,000 people & 191 & 6,83 & 150,1 & 6,42 & 239,6 & 7,25 & 294,6 & 7,5 \\
\hline TV Sets per 1,000 People & 422 & 6,8 & 475 & 7,42 & 538 & 8,12 & 409 & 6,56 \\
\hline \begin{tabular}{|l} 
Radios per 1,000 People \\
\end{tabular} & 523 & 6,41 & 690 & 7,5 & 803 & 8,36 & 965 & 8,83 \\
\hline $\begin{array}{l}\text { Daily Newspapers per } 1,000 \\
\text { People }\end{array}$ & 102 & 5,57 & 162 & 7,09 & $\mathrm{n} / \mathrm{a}$ & $\mathrm{n} / \mathrm{a}$ & 131 & 6,08 \\
\hline Internet Hosts per 10,000 People & 70,5 & 6,32 & 492,13 & 8,32 & 376,13 & 8 & 226,33 & 7,04 \\
\hline Internet users per 10,000 people & 2334,57 & 6,48 & 2746,4 & 6,8 & 4693,92 & 8,12 & 4209,36 & 7,97 \\
\hline $\begin{array}{l}\text { International } \\
\text { Telecommunications, Cost of } \\
\text { Call }\end{array}$ & 1,79 & 5,92 & 0,79 & 8,03 & 0,83 & 7,76 & 0,79 & 8,03 \\
\hline \begin{tabular}{|l|} 
E-Government Services \\
\end{tabular} & 2,2 & 2,99 & 2,87 & 5,36 & 2,73 & 4,85 & 2,87 & 5,36 \\
\hline Extent of Business Internet Use & 3,9 & 6,04 & 4 & 6,23 & 4,6 & 7,45 & 3,8 & 5,57 \\
\hline ICT Expenditure as \% of GDP & 4,5 & 2,75 & 6,1 & 5,65 & $\mathrm{n} / \mathrm{a}$ & $\mathrm{n} / \mathrm{a}$ & 5,3 & 3,77 \\
\hline
\end{tabular}

\section{The role of universities}

As Wiwczaroski writes, the " 21 st century will surely see an increasingly interdependent world"...and although "the Bologna Declaration sets out key tasks, the most challenging of which include the adoption of a common framework," many products of universities "are simply untranslatable in their present forms and contexts" $(2005,211)$. If European universities are to play their full role in the creation of a Europe of knowledge, European universities must face a number of challenges.

- European higher education is fragmented into (what are often) small national systems and subsystems, without effective links and bridges between them;

- National regulations are too often over-detailed, and this diminishes universities' responsiveness to changing learning and research needs emerging from markets and society;

- Europe's universities have a tendency to uniformity within each system/subsystem which has led to a good average level, but has limited access and failed to enable enough world-class research;

- Universities under-use the knowledge they produce because they and business still inhabit largely separate worlds;

- Many universities are insufficiently prepared for the coming competition for students, researchers and resources in an increasingly globalising world.

- Most importantly, funding for universities is far too low compared to our major competitors, both in education and in research, due mainly to much smaller contributions from private sources.

- Furthermore, access rates to higher education are still lower in Europe than in many other leading world regions, especially for adult learners

What does the Commission propose to do about the problem?

- Break down the barriers around universities in Europe There 
should be a major effort to achieve the core Bologna reforms by 2010 in all EU countries. These are:

- universality of the $\mathrm{BA} / \mathrm{MA} / \mathrm{PhD}$ structure;

- flexible, modernised curricula at all levels; and

- trustworthy quality assurance systems.

- Create real autonomy and accountability for universities. Member States should draw up a framework of rules and policy objectives for the higher education sector as a whole. Such rules would cover, for example, issues such as performance assessment, cost transparency, recruitment procedures, staff promotion mechanisms and tenure systems. Within this context universities should have the freedom and the responsibility to set their own missions, priorities and programmes in research, education and innovation; to decide on their own organisation and on the bodies necessary for their internal management and the representation of society's interests; to manage their own physical, financial and intellectual assets for research and education, their budgets (including fundraising) and their partnerships with academia and industry; to recruit and set the compensation rules for their permanent and temporary staff and to target their collective efforts towards institutional priorities in research, teaching and services. In doing so, universities need to accept that they are fully accountable to society as a whole for their results, including the cost-efficiency with which these are achieved. Member States should build up and reward management and leadership capacities within universities. The Commission suggests this could be done by establishing national bodies dedicated to university management and leadership training and using EU support to create strong linkages of them at European level.

- Provide incentives for structured partnerships with the business community Member States should support universities to develop incentive mechanisms to improve the use of knowledge and the wider sharing of research results, including intellectual property rights, patents, licensing and the creation of innovative spin-offs. Universities should build up lasting partnership with the business community, in particular by working with local and regional partners (research laboratories, science parks, start-ups and SMEs), for example by creating "clusters for knowledge creation and transfer". Universities should also be encouraged to establish universityindustry research partnership offices at the interface between the two sectors.

- Provide the right skills and competencies for the labour market The current pressure for uniformity - or even conformity - in much national regulation for universities does not enable sufficiently differentiated programmes geared towards the needs of different types of learners and regional/local actors. Member States should value and reward diverse university profiles, including thorough differentiated regulatory and funding systems. Programmes should be designed to enhance the employability of graduates. Research candidates should have the opportunity to acquire skills in IPR management, communication, networking, entrepreneurship and team-work in addition to research techniques. While university education and research pursue much broader ethical, cultural and social goals than "employability"

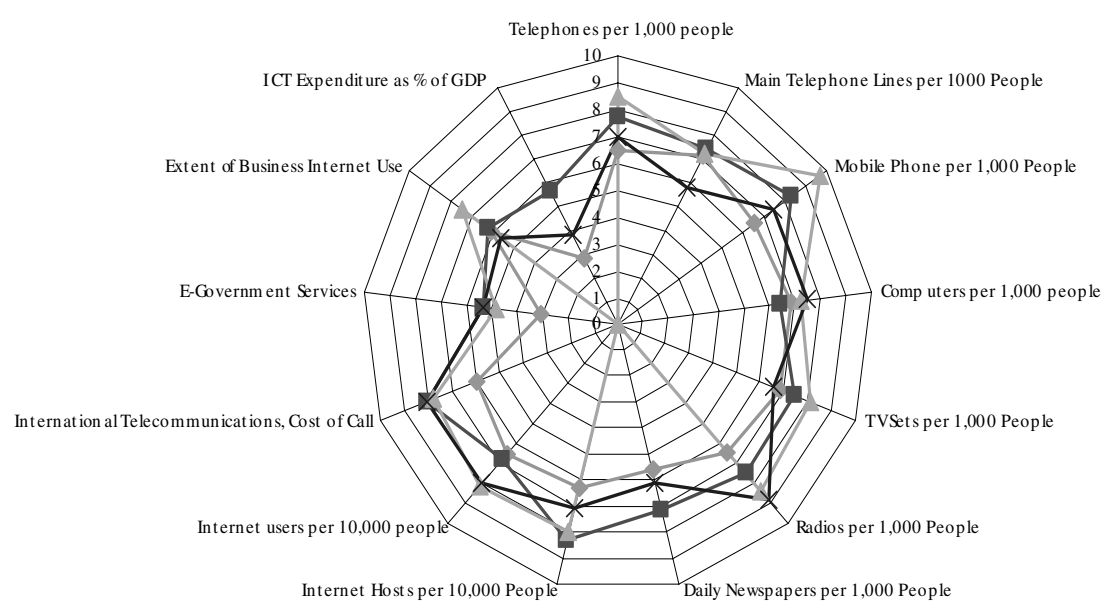

Poland normalized $\rightarrow$ - Slovakia normalized $-\leftarrow$ Hun gary normalized $\rightarrow$ Czech Rep ublicnormalized

Graph 4: Comparison of V4 Countries - ICT 
alone, labour market access should be used as one indicator, among many, of the quality of university performance. Universities will soon be faced with the consequences of an ageing population, with a dwindling potential pool of graduates. By providing more courses open to students at later stages of life, they will be better prepared to meet this challenge.

- Reduce the funding gap and make funding work harder in education and research There is a significant funding gap in Europe compared to its major competitors. In simple terms, to close the funding gap with the USA, Europe would need to spend - on average - an additional EUR 10,000 per higher education student per year. However, the bulk of this would need to come from non-public sources, i.e. from households, industry and donations. To tackle this gap, Member States should adopt the target that within a decade total funding for a modernised higher education sector should not be less than $2 \%$ of GDP. Universities will not be able to make their full contribution to growth and to the Lisbon strategy with less. University financing should be comprehensible and transparent. It should be based on what universities do and not what they are. Universities should take greater responsibility for their own long-term financial sustainability, through working with industry, foundations and other private sources. Member States should critically examine their current model of student finance and support for efficiency and equity.

- Enhance interdisciplinarity and transdisciplinarity Teaching and research agendas should reflect new developments in existing fields and emerging areas of inquiry. This will require an approach that brings together various disciplines that have an impact on a specific research domain, for example renewable energy or nanotechnology. It would also imply closer links between related or complementary fields, such as humanities, social sciences or business studies. This necessarily implies a more open approach to staff management, evaluation and funding criteria, teaching, curricula and research.

- Activate knowledge through interaction with society As Europe moves towards becoming a knowledge society, society in general needs to be a part of the process. Therefore universities should consider how they interact with the society within which they operate, whether locally, regionally or nationally. This can be done through greater emphasis on lifelong learning, but also by communication through open door days, placements, forums for dialogue and community service.

- Acknowledge and reward excellence at the highest level. All Member States should review their provision at postgraduate levels (master and doctorate, including postdoctoral opportunities) and the disciplines concerned, in the light of their strategic objectives for higher education, research and innovation in the national and European context. In this way, each university would be encouraged to identify a limited number of fields where it can achieve excellence. Financial support should be made available on European level to develop excellence at graduate/doctoral schools and networks meeting key criteria such as:

- critical mass,

- trans- and inter-disciplinarity,

- a strong European dimension,

- backing from regional/national authorities and from industry,

- identified and recognised areas of excellence, and

- provision of post-doctoral opportunities.

Competition for excellence should be strengthened through the European Research Council: the European Research Council (ERC) will promote a European champions' league in "frontier research" by opening up competition among Europe's best and brightest.

- Make the European Higher Education Area and the European Research Area more visible and attractive in the world There should be serious effort to market European universities abroad. The Commission has begun this process, through the highly successful Erasmus Mundus and Marie-Curie programmes. Both are oversubscribed and should be expanded. A single Europewide internet portal already exists for researchers. A similar one should enable students to search across all EU countries to find and compare courses per specialisation, level and language. (COM, 2006).

\section{Reference}

Chen, D.H.C., Dahlman, C.J. (2005): The Knowledge Economy, the KAM Methodology and World Bank Operations, http://siteresources.worldbank.org/KFDLP/Resources/KAM_Paper _WP.pdf http://en.wikipedia.org/wiki/Knowledge_economy

The role of the universities in the Europe of knowledge, Communication from the Commission, Brussels, 05.02.2003, COM (2003) 58 final

L'Europe a besoin de moderniser ses universités, Communiqué de presse, Brussels, 10.05.2006, COM (2006) 205

Wiwczaroski, T.B. (2005): "Surviving Bologna: Integrating the Lektorátus into the Wider University Community" Nyelvek és Nyelvoktatás Europa és a Kárpát-Medence Régióban. XIV. Magyar Alkalmazott Nyelvészeti Kongresszus, Közlemények, Vol. 1/1, 211-216. 